\title{
Relationships of the Tangible and Intangible Elements of Tourism Products with Overall Customer Satisfaction
}

\author{
Tahir Albayrak ${ }^{1}$, Meltem Caber ${ }^{2+}$ and Şafak Aksoy ${ }^{3}$
}

\begin{abstract}
Tourism enterprises usually offer both tangible and intangible products to their customers which are complementary each other and perceived as the integral parts of a whole travel experience. Although the tangible and intangible products are dissimilar in characteristics, they can be distinguished by their effects on customer satisfaction or combined for improving customer satisfaction. In this study, hotel products have been categorized by their tangibility and intangibility as well as their influences on customer satisfaction. The sample of the research consisted of the customers of a tour operator from six countries (the Russian Federation, Ukraine, Belarus, Latvia, Tatarstan, and Kazakhstan) whose holiday destination was Antalya, Turkey. Regression analysis results showed that tangible elements of the products were more influential on overall customer satisfaction than intangible elements at the hotels. Only for customers from Latvia, intangible elements of the hotel were more influential on overall satisfaction. This study showed that customer perceptions about the tangible and intangible elements of the tourism products may be varied according to nationalities, although tourism products usually combine both elements.
\end{abstract}

Index Terms-Tangible, intangible, tourism product, satisfaction

\section{INTRODUCTION}

A destination may be viewed as an amalgam of individual products and experience opportunities that combine to form a total experience of the area visited (Murphy et al., 2000). Tourism products are served to foreign visitors by numerious local companies which sometimes operate in different sectors in the host country. However, in the tourism literature, researchers to a large extent have concentrated on such aspects as accommodation, transportation facilities, and services as the duration of the customer-company interactions at hotels and transportation vehicles are usually much longer and their influences on customers' overall satisfaction are much higher than other sectors. For this reason, it becomes necessary to identify and analyse the

\footnotetext{
${ }^{1}$ Assistant professor, Akdeniz University, School of Tourism and Hotel Management. Campus-Antalya/Turkey Tel: +90.242. 3106657 E-mail: tahiralbayrak@akdeniz.edu.tr

${ }^{2+}$ Instructor, corresponding author. Akdeniz University, Manavgat Vocational School. Emek Mah. 3049 Sokak No:1 Manavgat, Antalya/Turkey Tel: $\quad+90.242 .7433500 \quad$ Fax: +90.242 .7433502 E-mail: meltemcaber@akdeniz.edu.tr

${ }^{3}$ Professor , Akdeniz University, Faculty of Economics and Administrative Sciences. Campus-Antalya/Turkey Tel: +90.242 . 3101833 E-mail: safak@akdeniz.edu.tr
}

characteristics of tourism products with a view to customer satisfaction as well as future expectations of tourism firms.

Most of the tourism products are in the form of combinations of both tangibles and intangibles (Vassiliadis, 2008). Although some researchers recommend a holistic approach for evaluating tourism products, its components can be separable and measurable according to their tangibility and intangibility. In hotels, for example, although the traditional "core" tourism product is the accommodation facility, this is substantially "enriched" by other tangible and intangible elements. In today's hospitality sector, much more complicated and combined tourism products can be observed and obtained. Thus, hotel managers either may take the advantage of collaborative managerial strategies such as total quality management if they want to adopt a holistic approach or prefer to identify each department's or each product's characteristics for utilizing them more efficiently. In this study, the characteristics of tangible and intangible elements of hotel products together with their relationships with overall customer satisfaction were examined and interpreted.

\section{THEORETICAL BACKGROUND}

\section{A. Tourism Products (Tangible and Intangible Elements)}

Ashworth and Voogt (1990) describe the tourism product as a bundle of services and experiences (Vassiliadis, 2008). Gunn's (1988) model of the Tourist System denotes the tourism product as a complex consumptive experience that results from a process where tourists use multiple travel services during the course of their visit (information, transportation, accommodation, and attraction services) (Murphy, 2000).

In terms of marketing thinking, tourism product developers and marketers should be aware of what is normally included in a tourism product - both tangible and intangible elements (Xu, 2009).

One of the most popular approaches for understanding the tourism products in terms of tangibles and intangibles was the one put forward by Shostack (1982). She proposed a molecular model of an enterprise as being made up of a tangible and intangible nucleus surrounded by additional tangible or intangible elements (Jones and Lockwood, 2004). Shostack suggested the service blueprinting technique for describing the service process and noted that when one element in a molecule changes, it would effect the whole molecule (Chan and Swatman, 2005). In this way, the enterprise can be seen to be either tangible- or 
intangible-dominant but it stresses that a business is made up of a mixture of discrete elements that need not be of the same type (Jones and Lockwood, 2004). The overall structure of the businesses are determined by the characteristic of the core element together with the feature of each of the separate elements. The molecular model can successfully be transformed to the hotel product since it is composed of a set of separate but interrelated elements such as the design of the hotel, the room facilities, the food and beverages served, the service offered by the staff, the overall ambience of the establishment and so on.

\section{B. Customer Satisfaction}

Customer satisfaction is typically defined as an overall assessment of the performance of various attributes that constitute a product or a service (Bartikowski and Llosa, 2004). Choi (2004) states that overall customer satisfaction consists of multiple dimensions of a product or service in various hospitality areas including tourism (Haber and Lerner, 1999; Herrick and McDonald, 1992; Kozak and Rimmington, 2000), hotel (Heide et al., 1999), and gaming (Mayer et al., 1998). The visitor satisfaction depends on certain characteristics of the tourist product offered, such as transportation, accommodation, gastronomy, attractiveness and cost of the service (Pizam et al., 1978). Moreover, it is generally perceived as the final result of all activities carried out during the process of purchase and consumption and not only of observation and/or direct consumption of the product or service (Oliver, 1996). Tian-Cole and Cromption (2003) state that researchers have frequently focused on identifying the factors or facets to understand tourists' satisfaction judgements, that may contribute to tourists' total satisfaction (Geva and Goldman, 1991; Pizam et al, 1978; Ross and Iso-Ahola, 1991; Thach and Axinn, 1994). Fundamentally, as Dubrovski (2001) argued, consumer satisfaction is located at the center of marketing theory and is based on the premise that the profit is made through the process of satisfaction of consumers' demands (Wicks and Roethlein, 2009).
In tourism literature, studies about product categorization are quite limited. One of them is Heide et al.'s (1999) work which identified the key areas of importance to customer satisfaction with a hotel. The researchers used overall satisfaction with the hotel visit as dependent variable and business hotel products, consisting of three different departments (reception, housekeeping, and food and beverages) and tangibles or intangibles in the three departments, as independent variables (Choi, 2004). The researchers suggested that managers should concentrate resources on areas that have the highest importance for overall satisfaction, while reaching the "good enough" level of customer satisfaction for the noncore items.

\section{Methodology}

The sample of this study was made up of an incoming tour operator's customers to Antalya, Turkey during May 2009. As the main market of the tour operator was the Russian Federation and Commonwealth of Independent States (CIS), the majority of the customers were Russian visitors. Of the total 4079 returned questionnaires, $2752(69,1 \%)$ were the participants form the Russian Federation, 710 (17,8\%) from Ukraine, 293 (7,4 \%) from Belarus, and the rest was from the other CIS countries. Females were quite dominant in the sample $(68,7 \%)$, whose average age was 36,06 and preferred to stay 9,32 days at the destination. The original survey consisted of seventy five questions covering the whole vacation process and measured on a 5 point Likert scale. Those items related with the intangibles and tangibles at the hotels were selected from the survey and their relationship with the overall customer satisfaction was analysed. The overall customer satisfaction was measured by two questions: 1)“I am sure that the hotel aimed to offer a perfect holiday experience to me" and 2) "I think that the hotel perfectly serves to its customers". In Table 1, the means of the tangibles, intangibles, and customer satisfaction are shown.

TABLE 1: InTANGIBLES, TANGIBLES, AND Overall CUSTOMER SATISFACTION

\begin{tabular}{|c|c|c|c|}
\hline Intangibles (Services) & $\mathrm{N}$ & Mean & Std. Deviation \\
\hline The hotel guide was helpful and concerned & 4005 & 4,45 &, 882 \\
\hline $\begin{array}{l}\text { The hotel guide solved my problems and answered my } \\
\text { requests on time }\end{array}$ & 3949 & 4,43 & ,909 \\
\hline The hotel guide was vocationally sufficient & 3955 & 4,44 & ,878 \\
\hline The hotel guide showed friendly approach & 2648 & 4,41 & ,910 \\
\hline The hotel guide was always reachable and easy to contact & 2593 & 4,48 & ,848 \\
\hline The hotel guide's advices were useful & 2599 & 4,33 & ,950 \\
\hline The hotel personnel were helpful and concerned & 2653 & 4,42 & ,812 \\
\hline $\begin{array}{l}\text { The hotel personnel solved my problems and answered my } \\
\text { requests on time }\end{array}$ & 2647 & 4,29 & ,943 \\
\hline The hotel personnel were vocationally sufficient & 3930 & 4,30 & ,912 \\
\hline Animation services of the hotel were perfect & 2579 & 3,93 & 1,183 \\
\hline Welness\&spa services of the hotel were perfect & 2102 & 4,18 & ,937 \\
\hline Services of the hotel for children were perfect & 2152 & 4,13 & 1,049 \\
\hline Tangibles (Goods) & $\mathrm{N}$ & Mean & Std. Deviation \\
\hline I am satisfied with the food \& beverage quality of the hotel & 3946 & 4,12 & 1,088 \\
\hline The general atmosphere of the hotel was perfect & 3951 & 4,46 & ,805 \\
\hline
\end{tabular}




\begin{tabular}{|c|c|c|c|}
\hline Design of the hotel rooms was perfect & 2641 & 4,10 & ,957 \\
\hline The general cleanliness of the hotel was perfect & 3959 & 4,23 & 1,009 \\
\hline The swimming pool of the hotel was perfect & 2609 & 4,46 & ,792 \\
\hline $\begin{array}{l}\text { The prices of the extra services at the hotel were } \\
\text { reasonable }\end{array}$ & 2263 & 3,72 & 1,049 \\
\hline Overall Satisfaction & $\mathrm{N}$ & Mean & Std.Dev. \\
\hline $\begin{array}{l}\text { I am sure that the hotel aimed to offer a perfect holiday } \\
\text { experience to me }\end{array}$ & 2632 & 4,31 & ,908 \\
\hline I think that the hotel perfectly serves to its customers & 2612 & 4,21 & ,936 \\
\hline
\end{tabular}

The relationships between the tangibles, intangibles, and customer satisfaction were analysed by regression analysis. The results indicated that tangible elements had a relatively greater influence $(, 664)$ on overall customer satisfaction than intangible elements, although there is a general consensus in tourism literature that intangibles are essential parts of tourism companies and determinants of the competitiveness (Table 2).

TABLE 2: REGRESSION ANALYSIS RESULTS

\begin{tabular}{|c|c|c|c|c|c|}
\hline & \multicolumn{2}{|c|}{ Unstandardized Coefficients } & \multirow{2}{*}{$\begin{array}{c}\begin{array}{c}\text { Standardized } \\
\text { Coefficients }\end{array} \\
\text { Beta }\end{array}$} & \multirow[b]{2}{*}{$\mathrm{t}$} & \multirow[b]{2}{*}{ Sig. } \\
\hline & B & Std. Error & & & \\
\hline (Constant) &,- 361 &, 087 & & $-4,140$ &, 000 \\
\hline Tangible &, 794 &, 022 & ,664 & 36,713 &, 000 \\
\hline Intangible & 287 &, 024 & ,212 & 11,750 & 000 \\
\hline
\end{tabular}

Dependent Variable: Overall customer satisfaction

To compare the tangible-intangible elements' relationship with overall customer satisfaction by different nationalities, separate regression analyses for six countries were made. Resulting standardized beta coefficients are shown in Table 3. Except for Latvia, beta coefficients of the tangible elements were higher than those of intangible elements. However, the beta coefficient of the intangible elements for Kazakhstan was insignificant. In general, influences of the tangible elements on overall customer satisfaction were considerably higher and statistically significant than intangibles.

TABLE 3: REGRESSION ANALYSIS BY COUNTRIES

\begin{tabular}{lcccc}
\hline & \multicolumn{3}{c}{ Standardized Beta Coefficient } \\
\cline { 2 - 5 } Country & $\mathrm{N}$ & Valid Percent (\%) & Tangible & Intangible \\
\hline Russian Fed. & 2752 & 69,1 & 0,492 & 0,380 \\
Ukraine & 710 & 17,8 & 0,612 & 0,275 \\
Belarus & 293 & 7,4 & 0,639 & 0,280 \\
Latvia & 116 & 2,9 & 0,390 & 0,522 \\
Tatarstan & 40 & 1,0 & 0,650 & $0,319 *$ \\
Kazakhstan & 73 & 1,8 & 0,713 & $0,197 * *$ \\
Total & 3984 & 100,0 & & \\
\hline * significant at 0,05 level; ** insignificant; all the others are significant at 0,01 level
\end{tabular}

Because of the limited size and distribution of the sample by nationalities, the results of the regression analysis could not be generalized to the tourism industry. However, the results were sufficient enough to show that the perceptions of the customers were significant in terms of tangible and intangible elements of the products. The results can be summarized as: 1) the hotel products and their characteristics are separable; 2 ) each type of the product may have different level of influence on customer satisfaction; and 3) the tangible products are fundamental parts of the complete customer satisfaction and total quality of the hotels.

\section{CONCLUSION}

For researchers, identification of the tangible and intangible elements of the products is a starting point for understanding the critical characteristics of the products in the eyes of customers. Therefore, the intangibility and tangibility of the tourism products should be considered both separately and jointly when the total quality or customer satisfaction is in question. Besides, as Bowen and Schneider (1985) noted, because of the intangibility aspects of service delivery, managers have imperfect knowledge of 
"transformation" (e.g. specifying desired output) which results in productivity-quality gaps in many cases. Moreover, customer needs are the most important driver of new product and new service development, and essential information for tourism organisations wishing to avoid strategic drift (Dwyer and Edwards, 2009). The tangible or intangible needs of the tourists can be met by new products which can be purely tangible, intangible or a combination of both. However, the level of customer necessity, perception and satisfaction from these products may be varied according to their demographic characteristics or many other variables. Therefore, in future studies, the interrelationships between the tourism product and customer satisfaction can be analyzed using alternative variables which were not investigated in this study because of time limitations.

In summary, the results of this research have shown that tangible elements of the tourism products are more influential on overall customer satisfaction which can be more easily modifiable or renewable than intangibles. Therefore, it is suggested that hotels should pay particular attention to the tangible evidences in their operations for higher customer satisfaction (Jones and Lockwood, 2004).

\section{REFERENCES}

[1] G.J.Ashworth, H. Voogt. Selling the City.London: Bellhaven, 1990.

[2] R.Bagozzi. Principles of Marketing Management. MacMillan Publishing Co., New York. 1991

[3] B.Bartikowski, S. Llosa. Customer satisfaction measurement: comparing four methods of attribute categorisations.The Service Industries Journal 2004, 24(4):67-82.

[4] D.E.Bowen, B.Schneider. Boundary spanning role employees and the service encounter: some guidelines for management and research. In: The Service Encounter: Managing Employee/Customer Interaction in Service Businesses. (eds.) J.Czepiel, M.Solomon, C.Surprenant. Lexington, MA: Lexington Books.127-148.1985

[5] E.S.K. Chan, P.M.C. Swatman. An evolving model for the offering of eBusiness programs, Proceedings of the Collaborative Electronic Commerce Technology and Research Conference, Sydney, Australia, 13 July. 2005.

[6] J.J. Choi. Factors influencing state association planners' overall satisfaction with a convention experience. Journal of Convention \& Event Tourism 2004, 6(4): 65-79.

[7] D.Dubrovski. The role of customer satisfaction in achieving business excellence, Total Quality Management 2001, 12(7-8): 920

[8] L.Dwyer, D. Edwards. Tourism product and service innovation to avoid 'strategic drift', International Journal of Tourism Research 2009, 11: $321-335$.

[9] A.Geva, A.Goldman. Satisfaction measurement in guided tours. Annals of Tourism Research 1991, 10:398-409.

[10] C.A.Gunn, Tourism planning (2nd edition). New York: Taylor and Francis. 1988.

[11] S. Haber, M. Lerner. Correlations of tourist satisfaction. Annals of Tourism Research 1999, 26(2):445-449.

[12] M. Heide, K. Gronhaug, M.G.Engset. Industry specific measurement of consumer satisfaction: experiencesfrom the business traveling industry. International Journal of Hospitality Management 1999, 18: 201 - 213.

[13] T. A.Herrick, C.D.McDonald. Factors affecting overall satisfaction with a river recreation experience.Environmental Management 1992, 16(2): 243-247.

[14] M.Kozak, M.Rimmington. Tourist satisfaction with Mallorca, Spain, as an off-season holiday season.Journal of Travel Research 2000, 38(3): 260-269.

[15] K.J.Mayer, L. Johnson, C. Hu, S. Chen. Gaming customer satisfaction: an exploratory study. Journal of Travel Research 1998, 37(2): 178-183.

[16] P. Murphy, M.P. Pritchard, B.Smith, The destination product and its impact on traveller perceptions, Tourism Management 2000, 21: 43-52.

[17] R.L. Oliver. Satisfaction: A Behavioral Perspective on the Consumer. New York: McGraw-Hill. 1996.
[18] A.Pizam, Y. Neuman, A. Reichel. Dimension of tourist satisfaction with a destination area. Annals of Tourism Research 1978, 5(3): 314-322.

[19] E. L. Ross, S.E. Iso-Ahola. Sightseeing tourists' motivation and satisfaction, Annals of Tourism Research 1991, 18: 226-237.

[20] G.L.Shostack. How to design a service. European Journal of Marketing 1982, 16(1):49-63.

[21] S.V. Thach,C.N.Axinn. Patron assessments of amusement park attributes. Journal of Travel Research 1994, 32: 51-60.

[22] S. Tian-Cole, J.L.Cromption. A conceptualization of the relationships between service quality and visitor satisfaction, and their links to destination selection. Leisure Studies 2003, 22: 65-80.

[23] C.A.Vassiliadis. Destination product characteristics as useful predictors for repeat visiting and recommendation segmentation variables in tourism: a CHAID exhaustive analysis. International Journal of Tourism Research 2008, 10: 439-452.

[24] J.B. Xu. Perceptions of tourism products, article in press, Tourism Management 2009, doi:10.1016/j.tourman.2009.06.011

[25] dzxA.M.Wicks, C.J.Roethlein. A satisfaction-based definition of quality. Journal of Business \& Economic Studies 2009, 15(1): 82-97. 